Check for updates

Cite this: RSC Adv., 2017, 7, 43681

Received 31st July 2017

Accepted 29th August 2017

DOI: $10.1039 / c 7 r a 08409 a$

rsc.li/rsc-advances

\section{Efficient mineralization of phenol by a temperature-responsive polyoxometalate catalyst under wet peroxide oxidation at lower temperatures $\dagger$}

\author{
Yiming Li, Xueyan Zhang, Dan Zhang, Yue Li, Xiaohong Wang (DD* \\ and Shengtian Wang*
}

\begin{abstract}
Herein, a temperature-responsive polyoxometalate (POM) catalyst $\left[\mathrm{C}_{16} \mathrm{H}_{33}\left(\mathrm{CH}_{3}\right)_{3} \mathrm{~N}\right]_{3}\left[\mathrm{PO}_{4}\left\{\mathrm{WO}\left(\mathrm{O}_{2}\right)_{2}\right\}_{4}\right] /$ poly( $\mathrm{N}$-isopropylacrylamide) (abbreviated as $\left(\mathrm{C}_{16} \mathrm{PW}\left(\mathrm{O}_{2}\right)_{2} / \mathrm{PNIPAM}\right)$ was prepared and used in the catalytic wet peroxide oxidation (CWPO) of phenol under mild conditions. The POM catalyst $\mathrm{C}_{16} \mathrm{PW}\left(\mathrm{O}_{2}\right)_{2} /$ PNIPAM showed a higher degradation efficiency and mineralization of phenol with $\mathrm{H}_{2} \mathrm{O}_{2}$ at room temperature or even at lower temperature $\left(0^{\circ} \mathrm{C}\right)$ within a short time $(120 \mathrm{~min})$. The high efficiency at lower temperature was attributed to its temperature-responsive property, wherein the lattice of the temperature-sensitive polymer relaxed at lower temperature and then wrinkled at higher temperature. These characteristics also permitted $\mathrm{C}_{16} \mathrm{PW}\left(\mathrm{O}_{2}\right)_{2}$ /PNIPAM to be easily separated for recycling. The leaching test indicated that the POM catalyst exhibited excellent stability and little leaching and can be used as a thermosensitive catalyst for about six times. $\mathrm{C}_{16} \mathrm{PW}\left(\mathrm{O}_{2}\right)_{2} / \mathrm{PNIPAM}$ has potential application in the CWPO of phenol without the limitation of temperature and $\mathrm{pH}$ conditions.
\end{abstract}

\section{Introduction}

Agricultural processes and industrial manufacturing produce a large amount of wastewater including organic pollutants, ${ }^{1}$ which are toxic and hardly biodegradable. Therefore, a wide range of scientific studies have been conducted to develop new technologies, such as physical adsorption, photo-catalysis, and chemical oxidation, to achieve the effective purification of wastewater polluted with organic compounds such as phenol and its derivatives..$^{2-5}$ Among the reported degradation processes, the CWPO system has emerged as a clean and effective alternative $\mathrm{e}^{6-9}$ because it has significant oxidizing ability with harmless by-products and non-toxic substances and high degradation efficiency under mild conditions $\left(20-60{ }^{\circ} \mathrm{C}\right.$, atmospheric pressure). To date, some studies have been reported on the CWPO of phenol containing the catalysts of Fenton agents, metal oxides, and polyoxometalates (Table S1 $\dagger$ ). At present, the highest efficiency was obtained with nano-metallic particles with $100 \%$ degradation of phenol under ultrasound power $(500 \mathrm{~W})$ for $120 \mathrm{~min}$ and the molar ratio of phenol to catalyst to $\mathrm{H}_{2} \mathrm{O}_{2}$ was $1: 12.5: 170 .{ }^{10}$ However, there are three major drawbacks for Fenton or metal oxides: the need for the removal of the

Key Lab of Polyoxometalate Science of Ministry of Education, Northeast Normal University, Changchun 130024, P. R. China. E-mail: wangxh665@nenu.edu.cn; Tel: +86-431-85099759

$\dagger$ Electronic supplementary information (ESI) available. See DOI: 10.1039/c7ra08409a homogeneous catalyst, narrow acidic range of $\mathrm{pH}(\sim 3.0)$, and low utilization of hydrogen peroxide and low degree of mineralization, which lead to the limitation of their application. POM has a broad use in catalysis such as in wet air oxidation, ${ }^{11,12}$ photodegradation, ${ }^{13} \mathrm{CWPO}$ or as anchoring sites for single-atom metal catalysts. ${ }^{14,15}$ Our group developed the polyoxometalate $\left[\mathrm{C}_{16^{-}}\right.$ $\left.\mathrm{H}_{33}\left(\mathrm{CH}_{3}\right)_{3} \mathrm{~N}\right]_{4} \mathrm{H}_{2} \mathrm{SiV}_{2} \mathrm{~W}_{10} \mathrm{O}_{40}$ for the CWPO of phenol, and highest catalytic activity was obtained (a 91.6\% degradation efficiency, 93.2\% COD removal, and 85.5\% TOC reduction with the phenol to catalyst to $\mathrm{H}_{2} \mathrm{O}_{2}$ molar ratio of $1: 60: 156.4$ under ambient conditions for $90 \mathrm{~min}){ }^{16} \mathrm{~A}$ higher usage of $\mathrm{H}_{2} \mathrm{O}_{2}$ was required to achieve high efficiency, and it did not exhibit activity at lower temperatures. Despite the higher efficiency and higher degree of mineralization, the separation was relatively difficult due to its nanostructure. In addition, our city, Changchun, is located in the Northeast of China, where for up to six months, the temperature remains below $10^{\circ} \mathrm{C}$. Normal CWPO treating temperature does not favor the degradation of phenol in our city. Therefore, procedures with high efficiency and deep mineralization at low temperatures are of great value and highly desirable.

Thermoresponsive polymers exhibit very sensitive and reversible temperature-dependant water solubility, which have attracted significant attention in terms of the catalytic loading. ${ }^{17,18}$ In our desulfurization process based on POMs, we have designed temperature-responsive POMs $\left[\mathrm{C}_{16} \mathrm{H}_{33^{-}}\right.$ $\left.\mathrm{N}\left(\mathrm{CH}_{3}\right)_{3}\right]_{3}\left[\mathrm{PO}_{4}\left\{\mathrm{MO}\left(\mathrm{O}_{2}\right)_{2}\right\}_{4}\right] /$ PNIPAM $(\mathrm{M}=$ Mo and $\mathrm{W})$ using poly$N$-isopropylacrylamide (PNIPAM) as the support ${ }^{19}$ in the $\mathrm{H}_{2} \mathrm{O}_{2}$ 
oxidation of organic sulfurs. It was found that the thermoresponsive hybrid $\left[\mathrm{C}_{16} \mathrm{H}_{33} \mathrm{~N}\left(\mathrm{CH}_{3}\right)_{3}\right]_{3}\left[\mathrm{PO}_{4}\left\{\mathrm{MO}\left(\mathrm{O}_{2}\right)_{2}\right\}_{4}\right] /$ PNIPAM exhibited a novel switchable property based on a change of temperature: it dissolved in organic solvents at higher temperatures and became gradually insoluble upon decreasing the temperature; we speculated that these thermo-responsive POM hybrids could exhibit good activity in the CWPO of phenol, especially at lower temperatures.

Herein, we used a thermo-sensitive POM $\mathrm{C}_{16} \mathrm{PW}\left(\mathrm{O}_{2}\right)_{2} / \mathrm{PNI}-$ PAM hybrid in the CWPO of phenol at various temperatures. It exhibited fast adsorption and higher activity than its parent at room temperature and even at lower temperatures, showing great potential in the cold temperature region. In addition, the degradation procedure of phenol under CWPO using the abovementioned POM was studied (Scheme $\mathrm{S} 1 \dagger$ ).

\section{Experimental}

\subsection{Materials}

All reagents were of AR grade and used without further purification. A $0.72 \mathrm{mM}$ phenol solution was prepared. $\mathrm{C}_{16} \mathrm{PW}\left(\mathrm{O}_{2}\right)_{2} /$ PANIPAM was synthesized according to ref. 20 and characterized by IR spectroscopy.

\subsection{Physical measurement}

Elemental analysis was carried out using a Leeman Plasma Spec (I) ICP-ES and a P-E 2400 CHN elemental analyzer. The FT-IR spectra (4000-400 $\mathrm{cm}^{-1}$ ) were obtained using $\mathrm{KBr}$ discs via a Nicolet Magna 560 IR spectrometer. The ${ }^{31} \mathrm{P}$ MAS NMR spectra of the samples were obtained using a Bruker AVANCE III $400 \mathrm{WB}$ spectrometer equipped with a $4 \mathrm{~mm}$ standard bore CPMAS probe with the $\mathrm{X}$ channel tuned to $162 \mathrm{MHz}$. Scanning electron microscopy (SEM) and energy-dispersive X-ray spectroscopy (EDAX) were performed using a XL30 ESEM FEG at $25 \mathrm{kV}$ (PhilipsXL-30). Calorimetric measurements were performed using an SDT Q600 instrument from $16{ }^{\circ} \mathrm{C}$ to $80{ }^{\circ} \mathrm{C}$ at a scan rate of $0.5{ }^{\circ} \mathrm{C} \min ^{-1}$. The analysis of phenol during the reaction was performed using a closed reflux colorimetric method via a 756 CRT UV-vis spectrophotometer at a wavelength of $505 \mathrm{~nm}$. Total organic carbon (TOC) was monitored using a Shimadzu TOC-VCPH total organic carbon analysis system. Chemical oxygen demand (COD) was determined using a closed reflux colorimetric method via a 756 CRT UV-vis spectrophotometer at a wavelength of $600 \mathrm{~nm}$. The intermediates were analyzed via high pressure liquid chromatography (HPLC) with a UV detector using a YWG $(4.6 \mathrm{~mm} \times 150 \mathrm{~mm}, 10 \mu \mathrm{m})$ column. The mobile phase was a solution of $\mathrm{H}_{3} \mathrm{PO}_{4}(0.02 \% \mathrm{w} / \mathrm{w})$ in $\mathrm{H}_{2} \mathrm{O}$ /acetonitrile $(95 / 5 \mathrm{v} / \mathrm{v})$ with a flow rate of $0.7 \mathrm{~mL} \mathrm{~min} \mathrm{~m}^{-1}$.

\subsection{Preparation of $\mathrm{C}_{16} \mathrm{PW}\left(\mathrm{O}_{2}\right)_{2} / \mathrm{PNIPAM}$}

In a typical synthesis, $N$-isopropylacrylamide $(5 \mathrm{~g})$ and $N, N$ methylenebisacrylamide (MBA) $(0.04 \mathrm{~g})$ were dissolved in a dimethyl sulfoxide (DMSO) mixed solution (4 mL) containing $1.5 \mathrm{~g}$ of polyvinylpyrrolidone (PVP) and $0.02 \mathrm{~g}$ of Pluronic F-127 (PF127). Then, $0.03 \mathrm{~g}$ of the initiator ammonium persulfate (APS) was added to the abovementioned monomer solution.
The mixture was stirred magnetically at room temperature for $30 \mathrm{~min}$. The reaction mixture was poured into a $200 \mathrm{~mm}$ long test tube (inside diameter $12.5 \mathrm{~mm}$ ). The tube was clamped to a ring standing in a chamber drying oven at $25^{\circ} \mathrm{C}$. Then, $0.1 \mathrm{~g}$ $\mathrm{C}_{16} \mathrm{PW}\left(\mathrm{O}_{2}\right)_{2}$ was added to the upper layer of the mixture under stirring for $30 \mathrm{~min}$. The mixed solutions were cast on glass substrates, followed by gelation and drying at $60{ }^{\circ} \mathrm{C}$. The $\mathrm{C}_{16} \mathrm{PW}\left(\mathrm{O}_{2}\right)_{2} /$ PNIPAM was obtained in $80.3 \%$ yield.

\subsection{Catalytic procedure}

For the degradation of phenol in a water system, $0.01 \mathrm{~g}$ of the catalyst was suspended in a fresh aqueous phenol solution $\left(C_{0}\right.$ $=0.72 \mathrm{mM}, 5 \mathrm{~mL}, \mathrm{pH}=1.7)$ in a $25 \mathrm{~mL}$ three-neck flask at ambient temperature. Then, $0.15 \mathrm{~mL}$ of hydrogen peroxide $(30.0 \%)$ was added to the mixture under stirring to start the reaction. After the reaction, the catalyst was separated by centrifugation at $1600 \mathrm{rpm}$ for $10 \mathrm{~min}$, which resulted in two layers: the upper layer was the aqueous phase and the bottom layer was the solid phase containing the catalyst. The aqueous sample was obtained at different times and immediately tested and measured using a 4-aminoantipyrine spectrophotometric method $^{21}$ via a 756 CRT UV-vis spectrophotometer at a wavelength of $505 \mathrm{~nm}$, which detected the degradation of phenol. The degradation efficiency of phenol was calculated using the following formula:

$$
\text { Phenol degradation }(\%)=\left(C_{0}-C_{\mathrm{i}}\right) / C_{0}
$$

where $C_{0}$ is the initial phenol concentration in the liquid sample and $C_{\mathrm{i}}$ is the final phenol concentration in the liquid sample.

The utility of $\mathrm{H}_{2} \mathrm{O}_{2}$ was detected via the titration method with $\mathrm{Ce}\left(\mathrm{SO}_{4}\right)_{2} \cdot{ }^{22}$ The temperature-control $\mathrm{C}_{16} \mathrm{PW}\left(\mathrm{O}_{2}\right)_{2} / \mathrm{PNIPAM}$ catalyst was left in the bottom of the reactor and was obtained by decanting and washing three times with water. The obtained solid was desiccated under vacuum at $60{ }^{\circ} \mathrm{C}$ for $120 \mathrm{~min}$ for recycling. The leaching of POMs from the polymer was tested using ICP analysis.

\subsection{Adsorption experiment}

An adsorption experiment was carried out to determine the adsorption capacity of the catalyst for an aqueous phenol solution. In the adsorption experiment, $0.01 \mathrm{~g}$ of catalyst was suspended in a fresh aqueous phenol solution $\left(C_{0}=0.72 \mathrm{mM}\right.$, $5 \mathrm{~mL}, \mathrm{pH}=1.7$ ) in a $25 \mathrm{~mL}$ three-neck flask for $2 \mathrm{~h}$ at ambient temperature. Then, the solid phase was separated by filtration. The catalyst was dried under vacuum at $60{ }^{\circ} \mathrm{C}$ and then used in determining the adsorption effect of phenol by IR spectroscopy.

\subsection{Differential scanning calorimetry (DSC)}

Calorimetric measurements were carried out using an SDT Q600 instrument from $16{ }^{\circ} \mathrm{C}$ to $80{ }^{\circ} \mathrm{C}$ at a scan rate of $0.5{ }^{\circ} \mathrm{C} \mathrm{min}^{-1}$. Herein, $0.0006 \mathrm{mg}$ of the catalyst was used. The DSC curve was integral to obtain the latent heat of the phase change. 


\section{Results and discussion}

\subsection{Evaluation of the degradation efficiency}

A preliminary experiment was performed at $25{ }^{\circ} \mathrm{C}$ and under atmospheric pressure in the presence of $\mathrm{H}_{2} \mathrm{O}_{2}$ without the catalyst and with different catalysts including $\mathrm{C}_{16} \mathrm{PW}\left(\mathrm{O}_{2}\right)_{2}$, PNIPAM and $\mathrm{C}_{16} \mathrm{PW}\left(\mathrm{O}_{2}\right)_{2}$ /PNIPAM (Fig. 1). Without the catalyst, phenol was degraded negligibly (less than $8.0 \%$ ); this indicated that the oxidative ability of $\mathrm{H}_{2} \mathrm{O}_{2}$ was weak at room temperature and pressure (Fig. 1a). In addition, the degradation of phenol by $\mathrm{H}_{2} \mathrm{O}_{2}$ was enhanced to a maximum of $46.0 \%$ using PNIPAM (Fig. 1b) at $120 \mathrm{~min}$, whereas the phenol degradation reached $40.0 \%$ at $30 \mathrm{~min}$ and then hardly increased upon prolonging the reaction time. This may be attributed to the adsorption of phenol and no catalytic degradation for the support PNIPAM (Fig. S1a $\dagger$ ). Fig. $\mathrm{S} 1 \dagger$ displays the adsorption of phenol by PNIPAM and $\mathrm{C}_{16} \mathrm{PW}\left(\mathrm{O}_{2}\right)_{2} / \mathrm{PNIPAM}$, which shows some difference for these two species in the amount of adsorbed phenol. However, the adsorption amount of phenol per gram of the polymer was almost the same for $\mathrm{C}_{16} \mathrm{PW}\left(\mathrm{O}_{2}\right)_{2} / \mathrm{PNIPAM}$ and PNIPAM (Fig. S1b $\dagger$ ). This indicated that the decrease of phenol in the PNIPAM system was mainly attributed to the adsorption effect. In addition, the product distribution of the reaction system using PNIPAM was tested with only phenol; this also determined the adsorption of phenol and no oxidation occurred. These two aspects indicate that PNIPAM was the only support. Therefore, the decrease in phenol was mainly attributed to the adsorption of phenol by the polymer support, whereas the adsorption effect mainly depended on the polymer. Addition of POMs can significantly accelerate the degradation rates; $\mathrm{C}_{16} \mathrm{PW}\left(\mathrm{O}_{2}\right)_{2}$ exhibited a $70.3 \%$ degradation efficiency for about 120 min (Fig. 1c), whereas $\mathrm{C}_{16} \mathrm{PW}\left(\mathrm{O}_{2}\right)_{2} / \mathrm{PNIPAM}$ can catalyze the complete decomposition of phenol under the same reaction conditions (Fig. 1d). Therefore, the activity of the $\mathrm{C}_{16} \mathrm{PW}\left(\mathrm{O}_{2}\right)_{2} / \mathrm{PNIPAM}$ hybrid originated from $\mathrm{C}_{16} \mathrm{PW}\left(\mathrm{O}_{2}\right)_{2}$. The higher efficiency observed for $\mathrm{C}_{16} \mathrm{PW}\left(\mathrm{O}_{2}\right)_{2} / \mathrm{PNIPAM}$ was attributed to its temperature-responsive property in the water phase.

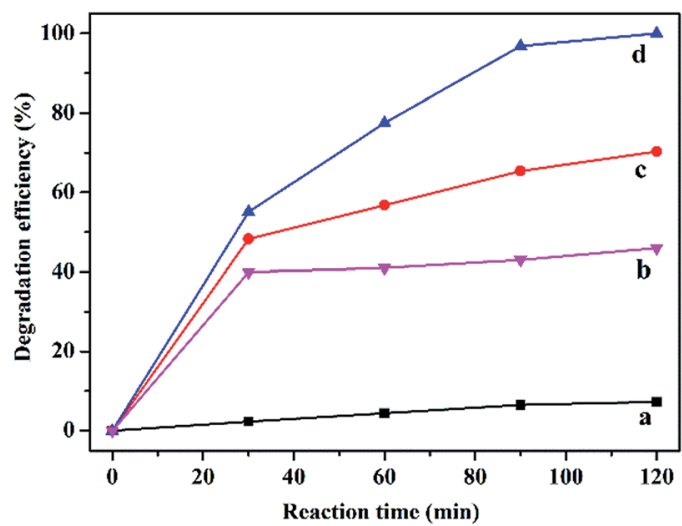

Fig. 1 The effect of different catalysts on the degradation of phenol. Blank (a), PNIPAM (b), $\mathrm{C}_{16} \mathrm{PW}\left(\mathrm{O}_{2}\right)_{2}$ (c), and $\mathrm{C}_{16} \mathrm{PW}\left(\mathrm{O}_{2}\right)_{2} /$ PNIPAM (d). Reaction conditions: PNIPAM (0.0084 g), $\mathrm{C}_{16} \mathrm{PW}\left(\mathrm{O}_{2}\right)_{2}(0.0016 \mathrm{~g})$, $\mathrm{C}_{16} \mathrm{PW}\left(\mathrm{O}_{2}\right)_{2}$ /PNIPAM $(0.01 \mathrm{~g}), \mathrm{H}_{2} \mathrm{O}_{2}(0.1 \mathrm{~mL})$, phenol solution (0.72 mM, $5 \mathrm{~mL}), 25^{\circ} \mathrm{C}, 2 \mathrm{~h}$.

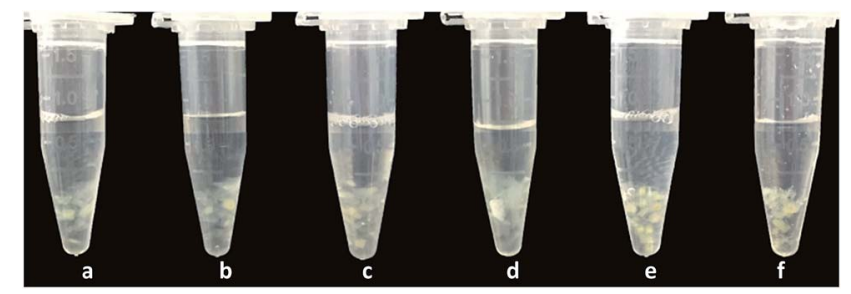

Fig. 2 Images of the phase changes observed for $\mathrm{C}_{16} \mathrm{PW}\left(\mathrm{O}_{2}\right)_{2} / \mathrm{PNI}-$ PAM at (a) $0{ }^{\circ} \mathrm{C}$, (b) $10{ }^{\circ} \mathrm{C}$, (c) $25^{\circ} \mathrm{C}$, (d) $32{ }^{\circ} \mathrm{C}$, (e) $45^{\circ} \mathrm{C}$, and (f) $60^{\circ} \mathrm{C}$.

It can be seen that $\mathrm{C}_{16} \mathrm{PW}\left(\mathrm{O}_{2}\right)_{2} / \mathrm{PNIPAM}$ exhibits a temperature-dependent relaxation in water (Fig. 2): at lower temperature, relaxation occurs in water, whereas at temperatures higher than $32{ }^{\circ} \mathrm{C}$, the catalyst wrinkles. In addition, the heat capacity of $\mathrm{C}_{16} \mathrm{PW}\left(\mathrm{O}_{2}\right)_{2} / \mathrm{PNIPAM}$ was measured using a DSC instrument. It can be seen that the peak at $32.93{ }^{\circ} \mathrm{C}$ is the temperature point of phase change with $\Delta H=113.5 \mathrm{~J} \mathrm{~g}^{-1}$ (Fig. S2†). The abovementioned results indicated that $\mathrm{C}_{16} \mathrm{PW}\left(\mathrm{O}_{2}\right)_{2} / \mathrm{PNIPAM}$ could exhibit different degrees of swelling, as also indicated in the UVvisible spectra of $\mathrm{C}_{16} \mathrm{PW}\left(\mathrm{O}_{2}\right)_{2}$ /PNIPAM in water upon varying the temperature (Fig. 3). It can be seen that the transmittance of $\mathrm{C}_{16} \mathrm{PW}\left(\mathrm{O}_{2}\right)_{2}$ /PNIPAM increased gradually upon increasing the temperature to $32^{\circ} \mathrm{C}$ and decreased at high temperature $\left(60^{\circ} \mathrm{C}\right)$. Therefore, the phase changes in $\mathrm{C}_{16} \mathrm{PW}\left(\mathrm{O}_{2}\right)_{2} / \mathrm{PNIPAM}$ occur upon varying the temperature; this is mainly attributed to PNIPAM.

Moreover, the higher activity of $\mathrm{C}_{16} \mathrm{PW}\left(\mathrm{O}_{2}\right)_{2} / \mathrm{PNIPAM}$ was attributed to the stronger adsorption of phenol (Fig. 4) by $\mathrm{C}_{16} \mathrm{PW}\left(\mathrm{O}_{2}\right)_{2}$ /PNIPAM. First, the adsorption of phenol by $\mathrm{C}_{16} \mathrm{PW}\left(\mathrm{O}_{2}\right)_{2} / \mathrm{PNIPAM}$ was determined using IR spectra at $1 \mathrm{~h}$ (Fig. 4). In comparison with those of $\mathrm{C}_{16} \mathrm{PW}\left(\mathrm{O}_{2}\right)_{2} / \mathrm{PNIPAM}$, the peaks originating from phenol at $1640 \mathrm{~cm}^{-1}$ shifted to $1659 \mathrm{~cm}^{-1}, 1292 \mathrm{~cm}^{-1}$ shifted to $1285 \mathrm{~cm}^{-1}, 981 \mathrm{~cm}^{-1}$ shifted to $969 \mathrm{~cm}^{-1}$, and $826 \mathrm{~cm}^{-1}$ shifted to $816 \mathrm{~cm}^{-1}$; this suggested that some interaction occurred between the $\mathrm{O}$ atom of phenolic hydroxyl and the terminal oxygen of $\left[\mathrm{PO}_{4}\left\{\mathrm{WO}\left(\mathrm{O}_{2}\right)_{2}\right\}_{4}\right]^{3-}$. In addition, the amount of phenol absorbed was measured

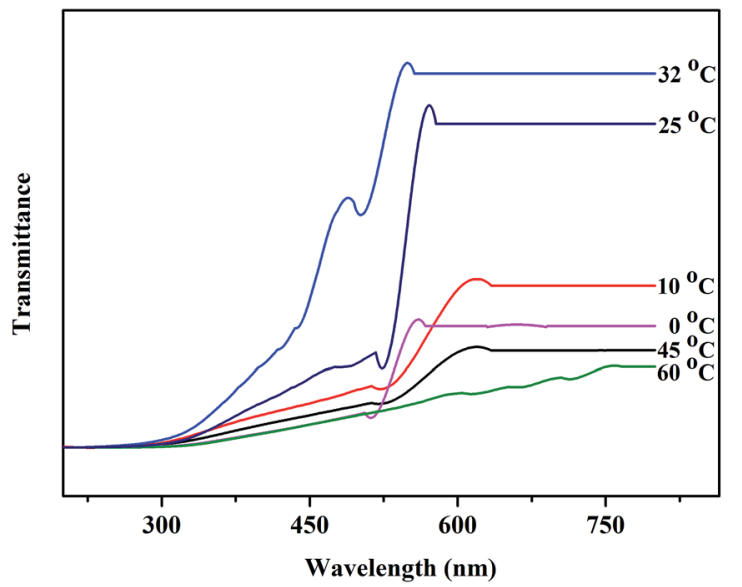

Fig. 3 The visible spectra of $\mathrm{C}_{6} \mathrm{PW}\left(\mathrm{O}_{2}\right)_{2} / \mathrm{PNIPAM}$ at different temperatures. 


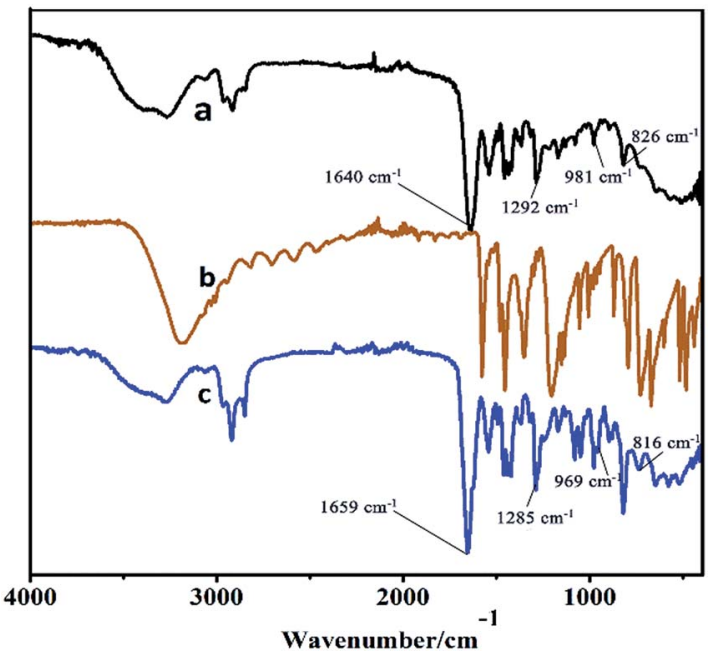

Fig. 4 The IR spectra of (a) $\mathrm{C}_{16} \mathrm{PW}\left(\mathrm{O}_{2}\right)_{2} / \mathrm{PNIPAM}$, (b) phenol, and (c) $\mathrm{C}_{16} \mathrm{PW}\left(\mathrm{O}_{2}\right)_{2} / \mathrm{PNIPAM}$-phenol at $25{ }^{\circ} \mathrm{C}$ for $0.5 \mathrm{~h}$.

(Fig. S1b†). It can be seen that $\mathrm{C}_{16} \mathrm{PW}\left(\mathrm{O}_{2}\right)_{2} / \mathrm{PNIPAM}$ can rapidly adsorb phenol molecules in $30 \mathrm{~min}$ and then saturation is reached after $30 \mathrm{~min}$. This adsorption of phenol can help them access the active sites in the POM; this promotes its oxidative degradation. Moreover, the adsorption of phenol by $\mathrm{C}_{16} \mathrm{PW}\left(\mathrm{O}_{2}\right)_{2}$ and $\mathrm{C}_{16} \mathrm{PW}\left(\mathrm{O}_{2}\right)_{2} / \mathrm{PNIPAM}$ depended on the temperature, and the adsorption capacity of $\mathrm{C}_{16} \mathrm{PW}\left(\mathrm{O}_{2}\right)_{2} / \mathrm{PNIPAM}$ was larger than that for $\mathrm{C}_{16} \mathrm{PW}\left(\mathrm{O}_{2}\right)_{2}$ below $25{ }^{\circ} \mathrm{C}$; in addition, at higher temperatures, $\mathrm{C}_{16} \mathrm{PW}\left(\mathrm{O}_{2}\right)_{2}$ showed a higher adsorption ability than the $\mathrm{C}_{16} \mathrm{PW}\left(\mathrm{O}_{2}\right)_{2} / \mathrm{PNIPAM}$ hybrid (Fig. 5). This difference was also attributed to the temperature-responsive property of $\mathrm{C}_{16} \mathrm{PW}\left(\mathrm{O}_{2}\right)_{2} /$ PNIPAM. As a result, $\mathrm{C}_{16} \mathrm{PW}\left(\mathrm{O}_{2}\right)_{2} /$ PNIPAM exhibited $29.9 \%$ higher activity than $\mathrm{C}_{16} \mathrm{PW}\left(\mathrm{O}_{2}\right)_{2}$ at a lower temperature of $25{ }^{\circ} \mathrm{C}$ (Fig. 6) and a significant degradation efficiency of $89.2 \%$ at $0{ }^{\circ} \mathrm{C}$.

To clarify the exact effect of $\mathrm{C}_{16} \mathrm{PW}\left(\mathrm{O}_{2}\right)_{2} / \mathrm{PNIPAM}$ on the conversion of phenol by $\mathrm{H}_{2} \mathrm{O}_{2}$, the COD and TOC changes were tested. It is known that the COD of water reflects the extent of

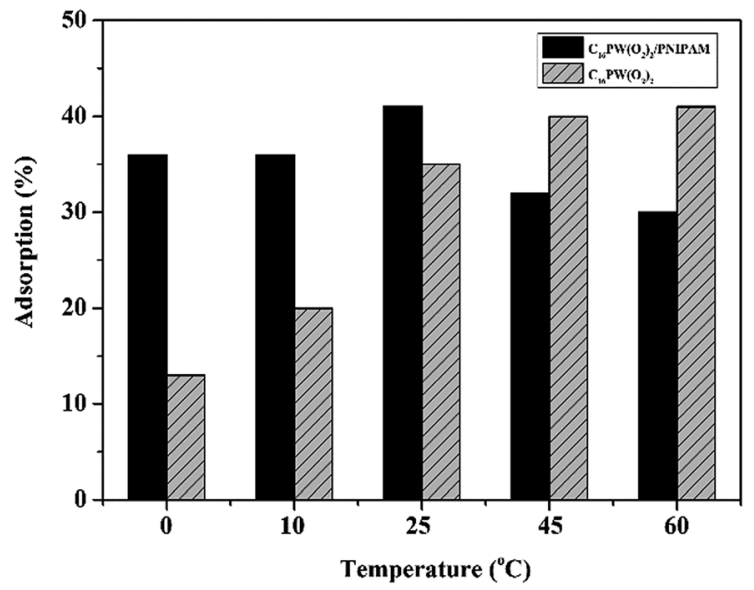

Fig. 5 Phenol adsorption on $\mathrm{C}_{16} \mathrm{PW}\left(\mathrm{O}_{2}\right)_{2} / \mathrm{PNIPAM}$ and $\mathrm{C}_{16} \mathrm{PW}\left(\mathrm{O}_{2}\right)_{2}$ at different temperatures.

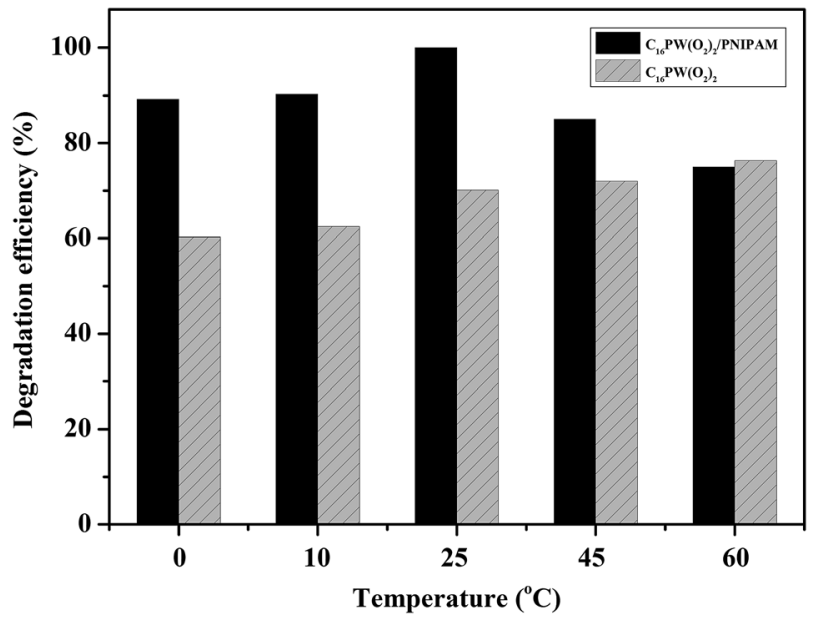

Fig. 6 The degradation efficiency between $\mathrm{C}_{16} \mathrm{PW}\left(\mathrm{O}_{2}\right)_{2} / \mathrm{PNIPAM}$ and $\mathrm{C}_{16} \mathrm{PW}\left(\mathrm{O}_{2}\right)_{2}$ at different temperatures.

contamination by a reductive substance, whereas the TOC refers to the total carbon content. At $120 \mathrm{~min}$, the COD and TOC were reduced to $98.8 \%$ and $\sim 100 \%$, respectively, indicating that it was the oxidative degradation of phenol and not an adsorptive effect. This indicates that the phenol molecules can be totally mineralized into simple inorganic compounds by $\mathrm{C}_{16} \mathrm{PW}\left(\mathrm{O}_{2}\right)_{2} /$ PNIPAM/ $/ \mathrm{H}_{2} \mathrm{O}_{2}$.

For further optimizing the degradation process with $\mathrm{C}_{16} \mathrm{PW}\left(\mathrm{O}_{2}\right)_{2} / \mathrm{PNIPAM}$, the reaction was performed at various temperatures, reaction times, $\mathrm{H}_{2} \mathrm{O}_{2}$ concentrations, $\mathrm{pH}$ values, catalyst dosages, and loading amounts, as shown in Fig. 7. Fig. 7a shows the relationship between the degradation efficiency and reaction temperature and time when the degradation of phenol is catalyzed by $\mathrm{C}_{16} \mathrm{PW}\left(\mathrm{O}_{2}\right)_{2} /$ PNIPAM. A little difference was found for various temperatures at $30 \mathrm{~min}$, indicating most of the adsorption of phenol by the hybrid occurred during this period. Then, the degradation efficiency increased upon prolonging the reaction time to $120 \mathrm{~min}$ at all the temperatures studied herein, and the best phenol conversion was found to be $\sim 100 \%$ at $25{ }^{\circ} \mathrm{C}$ at $120 \mathrm{~min}$. In addition, $100 \%$ degradation at $10{ }^{\circ} \mathrm{C}$ and $0{ }^{\circ} \mathrm{C}$ was obtained at $180 \mathrm{~min}$ and $200 \mathrm{~min}$, respectively. $\mathrm{C}_{16} \mathrm{PW}\left(\mathrm{O}_{2}\right)_{2} / \mathrm{PNIPAM}$ showed excellent performance at lower temperature; this was different from the previously reported results of $\left[\mathrm{C}_{16} \mathrm{H}_{33}\left(\mathrm{CH}_{3}\right)_{3} \mathrm{~N}\right]_{4} \mathrm{H}_{2} \mathrm{SiV}_{2} \mathrm{~W}_{10} \mathrm{O}_{40}{ }^{16}$ The changes in the COD and TOC are given in Fig. 7b, showing that the removal of COD and TOC increased gradually to almost $100 \%$ at $120 \mathrm{~min}$, in accordance with the phenol conversion. This result demonstrated that $\mathrm{C}_{16} \mathrm{PW}\left(\mathrm{O}_{2}\right)_{2} / \mathrm{PNIPAM}$ was more active in the CWPO treatment of phenol, whereas the intermediates formed during phenol degradation were oxidized to simple inorganic species as soon as they were formed. Further, the influence of the $\mathrm{pH}$ values on the degradation of phenol was investigated (Fig. 7c); it was observed that the degradation efficiency of phenol over $\mathrm{C}_{16} \mathrm{PW}\left(\mathrm{O}_{2}\right)_{2} / \mathrm{PNIPAM}$ at the $\mathrm{pH}$ values of $1.5,1.7,2.2,3.0,4.0,5.0,6.0$, and 7.0 were 96.8, 100, 96.0, $94.2,92.3,88.5,82.0$, and $74.9 \%$, respectively. The maximum degradation efficiency (100\%) was obtained at $\mathrm{pH} 1.7$. Upon increasing the $\mathrm{pH}$, the degradation of phenol decreased. 

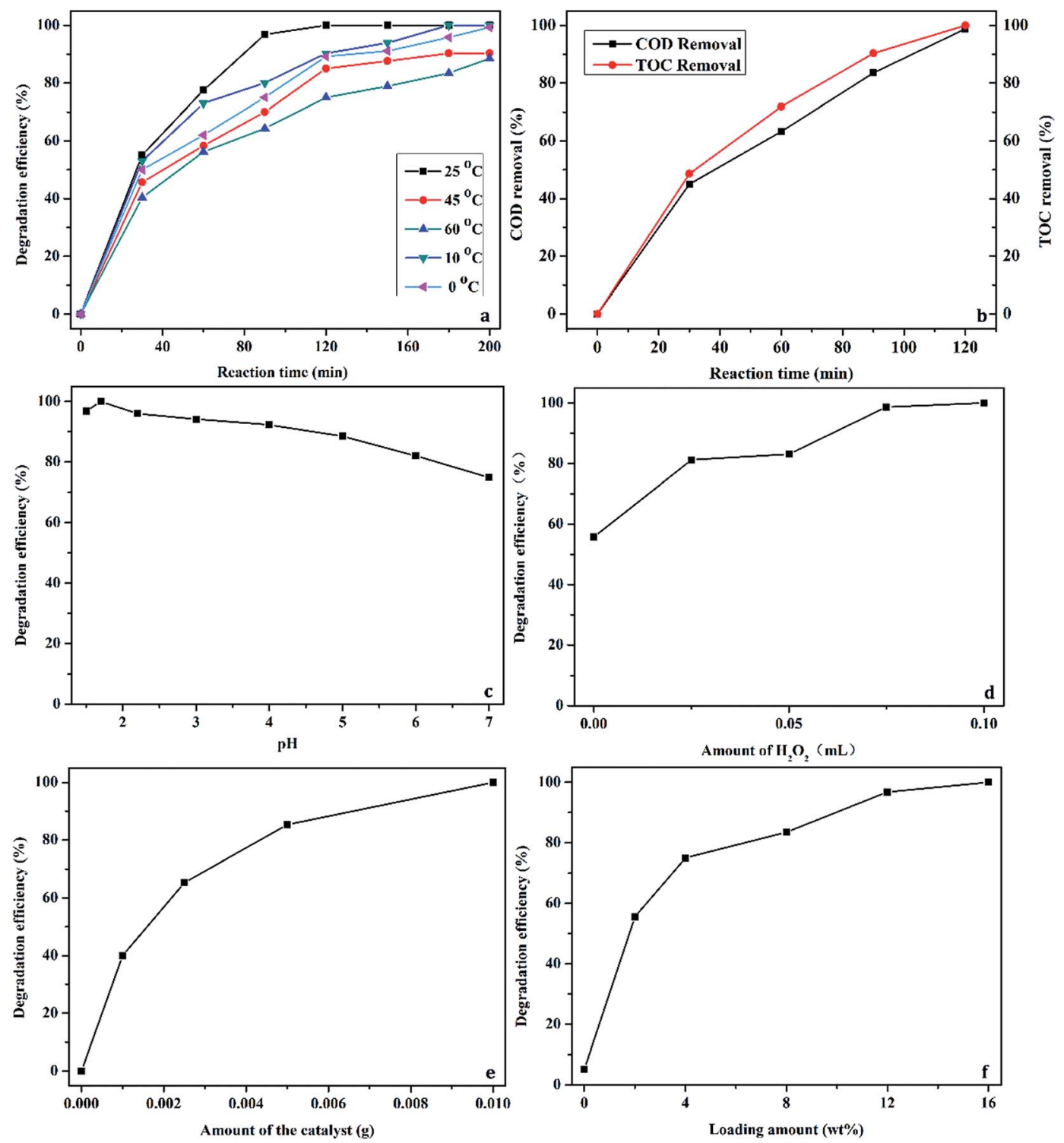

Fig. 7 The main parameters affecting the degradation of phenol: temperature (a), COD and TOC (b), pH (c), $\mathrm{H}_{2} \mathrm{O}_{2} \mathrm{concentration}(\mathrm{d}), \mathrm{catalyst}$ dosage, (e) and loading amount (f).

However, the degradation of phenol showed no significant difference in the $\mathrm{pH}$ range of $0-5$, with only about an $8 \%$ decrease. This result shows that $\mathrm{C}_{16} \mathrm{PW}\left(\mathrm{O}_{2}\right)_{2} / \mathrm{PNIPAM}$ can perform over a wide $\mathrm{pH}$ range. Upon further increasing the $\mathrm{pH}$ to 7 , the degradation is decreased to $74.9 \%$, which is also active, and upon prolonging the reaction time, $100 \%$ conversion of phenol can be achieved. This decrease may be attributed to an increase in the $\mathrm{pH}$ that leads to the ionization of phenol to form $\mathrm{Ph}-\mathrm{O}^{-}$. Because the surface charge of the POMs is negative, the phenol molecules are repelled far away from the catalytic centers; this results in a decrease in phenol adsorption by the catalyst and hence a decrease in the degradation efficiency. Fig. $7 d$ shows the effect of $\mathrm{H}_{2} \mathrm{O}_{2}$ concentration when the reaction is carried out at $25{ }^{\circ} \mathrm{C}$ for 120 min using $0.01 \mathrm{~g}$ of catalyst. Obviously, the degradation efficiency increased markedly when the concentration of $\mathrm{H}_{2} \mathrm{O}_{2}$ was increased to $0.1 \mathrm{~mL}$. In theory,
$14 \mathrm{~mol}$ of $\mathrm{H}_{2} \mathrm{O}_{2}$ is needed to oxidize $1 \mathrm{~mol}$ of phenol. To achieve a high degradation of phenol, an excess of $\mathrm{H}_{2} \mathrm{O}_{2}$ needs to be added. The optimal hydrogen peroxide concentration was $0.19 \mathrm{M}$ in our experiment, which was 19 times higher than stoichiometric concentration of $0.01 \mathrm{M}$. In addition, about 98.9\% $\mathrm{H}_{2} \mathrm{O}_{2}$ was consumed at $120 \mathrm{~min}$ in the presence of $\mathrm{C}_{16} \mathrm{PW}\left(\mathrm{O}_{2}\right)_{2} / \mathrm{PNIPAM}$. This also indicated that some organic intermediates were produced during the oxidation of phenol by $\mathrm{H}_{2} \mathrm{O}_{2}$. Then, further increase in the $\mathrm{H}_{2} \mathrm{O}_{2}$ used did not lead to a higher degradation efficiency due to the decomposition of $\mathrm{H}_{2} \mathrm{O}_{2}$. This usage was smaller than the previous results reported for $\left[\mathrm{C}_{16} \mathrm{H}_{33}\left(\mathrm{CH}_{3}\right)_{3} \mathrm{~N}\right]_{4} \mathrm{H}_{2} \mathrm{SiV}_{2} \mathrm{~W}_{10} \mathrm{O}_{40}{ }^{16}$

Fig. 7e shows the effect of the catalyst dosage on the degradation of phenol. Upon increasing the catalyst dosage from 0.001 to $0.01 \mathrm{~g}$, the degradation efficiency was increased from 40 and $100 \%$, respectively. The result can be attributed to an 
increase in the number of catalytic active sites in the catalyst. When the amount of catalyst was increased to $0.01 \mathrm{~g}$, the degradation efficiency of phenol improved slowly. Therefore, $0.01 \mathrm{~g}$ was selected as the most appropriate amount of catalyst with a high degradation efficiency. The loading amount of $\mathrm{C}_{16} \mathrm{PW}\left(\mathrm{O}_{2}\right)_{2}$ had a significant influence on the degradation efficiency of phenol (Fig. 7f). The degradation efficiency increased as the loading amount of POMs was increased. In addition, the degradation efficiency was 55.6, 75.0, 83.5, 96.8, and $100 \%$ at a loading amount of $2.0,4.0,8.0,12.0$, and $16.0 \mathrm{wt} \%$, respectively. If the loading amount continued to increase, $\mathrm{C}_{16} \mathrm{PW}\left(\mathrm{O}_{2}\right)_{2} / \mathrm{PNIPAM}$ was unable to display the temperature-responsive property.

\subsection{Reusability of catalyst}

The stability of a catalyst is one of the most important factors in the heterogeneous CWPO process. The FTIR spectra of the recovered $\mathrm{C}_{16} \mathrm{PW}\left(\mathrm{O}_{2}\right)_{2} / \mathrm{PNIPAM}$ was investigated (Fig. $\mathrm{S} 3 \dagger$ ). In the IR spectrum of fresh $\mathrm{C}_{16} \mathrm{PW}\left(\mathrm{O}_{2}\right)_{2} / \mathrm{PNIPAM}$, the peaks (Fig. S3a $\dagger$ ) at 1166, 981, 826, and $723 \mathrm{~cm}^{-1}$ were usually assigned to $\nu(\mathrm{P}-\mathrm{O}), \nu(\mathrm{W}=\mathrm{O}), \nu(\mathrm{O}-\mathrm{O})$, and $\nu\left[\mathrm{W}\left(\mathrm{O}_{2}\right)\right]$, respectively. These peaks suggest the existence of the $\left[\mathrm{PO}_{4}\left\{\mathrm{WO}\left(\mathrm{O}_{2}\right)_{2}\right\}_{4}\right]^{3-}$ group in the hybrid. In addition, the peaks at 2930 and $1455 \mathrm{~cm}^{-1}$ were due to $\mathrm{N}-\mathrm{H}, \mathrm{C}-\mathrm{H}$, and $\mathrm{C}-\mathrm{N}$ in $\left[\mathrm{C}_{16} \mathrm{H}_{33} \mathrm{~N}\left(\mathrm{CH}_{3}\right)_{3}\right]^{+}$. The three characteristic peaks at 3270,1640 , and $1290 \mathrm{~cm}^{-1}$ can be attributed to $\nu(-\mathrm{NH}-\mathrm{C}=\mathrm{O})$, which are the intense vibrations of PNIPAM. As compared to the IR spectrum of $\mathrm{C}_{16} \mathrm{PW}\left(\mathrm{O}_{2}\right)_{2},{ }^{23}$ some red shifts of the $\nu(\mathrm{W}=\mathrm{O}), \nu(\mathrm{O}-\mathrm{O})$, and $\nu_{\text {asym }}\left[\mathrm{W}\left(\mathrm{O}_{2}\right)\right]$ occurred; this indicated the existence of some interactions between $\mathrm{C}_{16} \mathrm{PW}\left(\mathrm{O}_{2}\right)_{2}$ and PNIPAM. ${ }^{24}$ These interactions were attributed to the hydrogen bonds formed between the terminal oxygens of $\mathrm{C}_{16} \mathrm{PW}\left(\mathrm{O}_{2}\right)_{2}$ and the $\mathrm{NH}$ groups in PNIPAM, which confirmed the little leaching of POMs from PNIPAM. The IR spectrum of the recovered $\mathrm{C}_{16} \mathrm{PW}\left(\mathrm{O}_{2}\right)_{2} / \mathrm{PNIPAM}$ showed no changes in the characteristic peaks for $\left[\mathrm{C}_{16} \mathrm{H}_{33} \mathrm{~N}\left(\mathrm{CH}_{3}\right)_{3}\right]^{+}$, $\left[\mathrm{PO}_{4}\left\{\mathrm{WO}\left(\mathrm{O}_{2}\right)_{2}\right\}_{4}\right]^{3-}$, and PNIPAM; this indicated the stability of $\mathrm{C}_{16} \mathrm{PW}\left(\mathrm{O}_{2}\right)_{2} / \mathrm{PNIPAM}$ during the oxidative reaction. The DR-UVvis spectra of $\mathrm{C}_{16} \mathrm{PW}\left(\mathrm{O}_{2}\right)_{2} / \mathrm{PNIPAM}$ (Fig. S4a $\dagger$ ) had a significant characteristic peak at $240 \mathrm{~nm}$. In addition, $\mathrm{C}_{16} \mathrm{PW}\left(\mathrm{O}_{2}\right)_{2} / \mathrm{PNIPAM}$ after the degradation of phenol (Fig. $\mathrm{S} 4 \mathrm{~b} \dagger$ ) was the same as the original. The stability of the catalyst was also demonstrated by ${ }^{31} \mathrm{P}$ magic-angle spinning (MAS) NMR spectroscopy (Fig. S5 $\dagger$ ). The ${ }^{31} \mathrm{P}$ MAS NMR spectrum of $\mathrm{C}_{16} \mathrm{PW}\left(\mathrm{O}_{2}\right)_{2} / \mathrm{PNIPAM}$ after the reaction further determined its stability during the oxidation reaction. The morphology of $\mathrm{C}_{16} \mathrm{PW}\left(\mathrm{O}_{2}\right)_{2} / \mathrm{PNIPAM}$ before and after the oxidative reaction was examined by SEM (Fig. S6a $\dagger$ ), showing that no changes occurred during the reaction. Therefore, the $\mathrm{C}_{16} \mathrm{PW}\left(\mathrm{O}_{2}\right)_{2} / \mathrm{PNIPAM}$, as characterized by IR spectra, DR-UV-vis spectra, ${ }^{31} \mathrm{P}$ MAS NMR spectra, and SEM before and after the degradation of phenol, kept its original structure and morphology. The results showed that the catalyst remained perfectly organized after the reaction. Moreover, the catalyst retained its high efficiency in the process of phenol degradation after six repeated experiments. Therefore, the leaching test revealed that $\mathrm{C}_{16} \mathrm{PW}\left(\mathrm{O}_{2}\right)_{2} / \mathrm{PNIPAM}$ had fantabulous stability and could be reused six times as a rapid thermosensitive catalyst via a simple treatment. Moreover, the total amount of $\mathrm{C}_{16} \mathrm{PW}\left(\mathrm{O}_{2}\right)_{2} / \mathrm{PNIPAM}$ leaching through the six runs of the reaction reached only $7.4 \%$ of the starting amount, as ascertained by ICP (Table S2†) measurements (Fig. 8).

\subsection{Catalytic reaction mechanisms of the CWPO process}

Generally, it has been shown that the oxidation process of organic molecules by POMs occurs via a free radical mechanism..$^{25,26}$ Superoxide radicals $\left(\mathrm{O}_{2}{ }^{-}\right)$are extremely highpotential oxidizing agents with short lifetimes and can oxidize organic substrates and generate other free radicals. ${ }^{27}$ To confirm the main active radicals responsible for the degradation of phenol catalyzed by $\mathrm{C}_{16} \mathrm{PW}\left(\mathrm{O}_{2}\right)_{2} / \mathrm{PNIPAM}$, a comparative experiment was carried out by adding $10 \mathrm{wt} \%$ of the catalyst quenchers into the initial solution under the same conditions (Fig. 9). The possible oxidative intermediate radicals, such as singlet oxygen $\left({ }^{1} \mathrm{O}_{2}\right)$, superoxide $\left(\mathrm{O}_{2}{ }^{-}\right)$, hydroperoxy $\left(\mathrm{HO}_{2}{ }^{\circ}\right)$ or $\left(\mathrm{OH}^{\circ}\right)$, were demonstrated indirectly through the use of appropriate quenchers for these radicals based on otherwise identical conditions. Certain quenchers include KI (a quencher of $\mathrm{OH}^{*}$ radicals on the catalyst surface $\left.{ }^{28}\right)$, sodium azide $\left(\mathrm{NaN}_{3}\right.$, a singlet oxygen quencher, ${ }^{29}$ but may also interact with $\mathrm{OH}^{\cdot}$ radicals $^{30}$ ), and $p$-benzoquinone $\left(\mathrm{C}_{6} \mathrm{H}_{4} \mathrm{O}_{2}, \mathrm{BQ}\right.$, a quencher of the superoxide radical $\left.^{31}\right)$. The addition of $p$-benzoquinone had an influence on the process of phenol degradation; this suggested that the active oxidative species in this system was a combination of $\mathrm{O}_{2}{ }^{\cdot-}$ and singlet oxygen $\left({ }^{1} \mathrm{O}_{2}\right)$ free radicals. The effect of $p$-benzoquinone was much higher than that of $\mathrm{KI}$ and higher than that of $\mathrm{NaN}_{3}$; this indicated that $\mathrm{O}_{2}{ }^{-}$- was formed as a possible oxidative intermediate species during the reaction. However, KI promotes the degradation of phenol. It might be $\mathrm{I}^{-}$ enhancing the transmission of electrons and accordingly improving the transmission of the peroxy-chain. The abovementioned results indicate that the reaction of phenol oxidation underwent a superoxide radical and single oxygen mechanism.

Therefore, the mechanism of CWPO degradation of phenol over $\mathrm{C}_{16} \mathrm{PW}\left(\mathrm{O}_{2}\right)_{2} / \mathrm{PNIPAM}$ catalyst was proposed as follows:

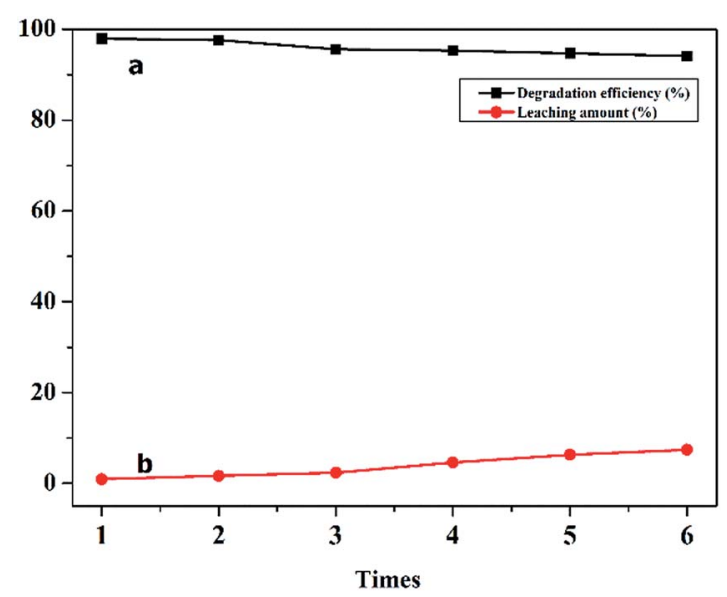

Fig. 8 The reuse of $\mathrm{C}_{16} \mathrm{PMo}\left(\mathrm{O}_{2}\right)_{2} /$ PNIPAM (a) and the amount of $\mathrm{C}_{16} \mathrm{PMo}\left(\mathrm{O}_{2}\right)_{2}$ leached from the polymer (b). 


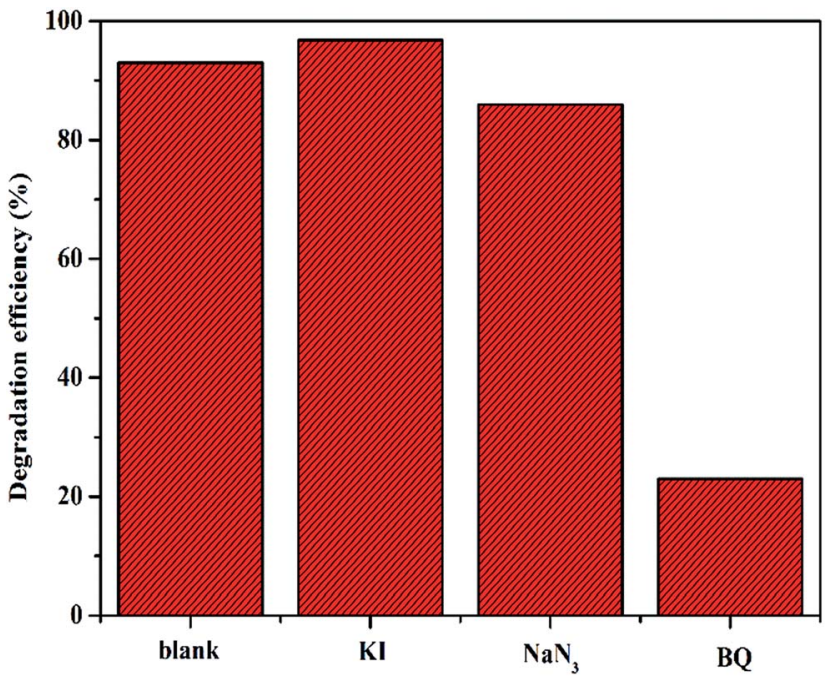

Fig. 9 The effects of scavenging agents including $\mathrm{KI}, \mathrm{NaN}_{3}$, and 1,4benzoquinone $(\mathrm{BQ})$ on the degradation of phenol. Reaction conditions: $\mathrm{C}_{16} \mathrm{PW}\left(\mathrm{O}_{2}\right)_{2} / \mathrm{PNIPAM}(0.01 \mathrm{~g})$, scavenging agents: $10 \mathrm{wt} \%$ of the catalyst, $\mathrm{H}_{2} \mathrm{O}_{2}(0.1 \mathrm{~mL})$, phenol solution $(0.72 \mathrm{mM}, 5 \mathrm{~mL}), 25^{\circ} \mathrm{C}, 2 \mathrm{~h}$.

(1) the reactants (phenol and $\mathrm{H}_{2} \mathrm{O}_{2}$ ) were adsorbed on the expansive membrane by the transmission peroxide chain via the interaction between hydrogen peroxide and the $\mathrm{O}-\mathrm{O}$ chain in $\mathrm{C}_{16} \mathrm{PW}\left(\mathrm{O}_{2}\right)_{2}$. Then, the phenol molecules were accessible to the active sites anchored within micellar particles of $\mathrm{C}_{16} \mathrm{PW}\left(\mathrm{O}_{2}\right)_{2}$ in the lattice of PNIPAM (Scheme 1). This adsorption reached an equilibrium after the suspension was stirred for 30 min; (2) the $\mathrm{POM}_{\text {red }}$ was formed. Then, $\mathrm{O}_{2}{ }^{-{ }^{-}}$can be formed via an $\mathrm{O}-\mathrm{O}$ chain auto-oxidation process in the presence of $\mathrm{H}_{2} \mathrm{O}_{2}$, such that the organic molecules can be degraded by the radical to accomplish the degradation of phenol. Phenol was oxidized first into catalysts and the peroxo-group was transferred to phenol molecules, while $R$-and reduced form of $p$ benzoquinone (abbreviated as $p$-BQ), and seldom $o$-benzoquinone (abbreviated as $o$-BQ) and then into oxalic acid (abbreviated as OA), formic acid (abbreviated as FA) and propionic acid (abbreviated as PA) measured by HPLC (Fig. 10). In the beginning of the reaction, the phenol molecules are mostly decomposed to OA and a small amount of FA and PA. Then, some of the oxalic acid molecules degraded to FA, which was tested during the degradation of oxalic acid under the same reaction conditions (Fig. S8 ${ }^{\dagger}$ ). Oxalic acid was rapidly degraded at the end of the reaction. In addition, they decomposed gradually and were totally mineralized into $\mathrm{CO}_{2}$ and water. (3) Finally, the

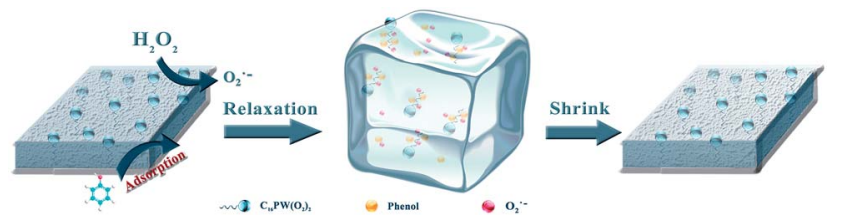

Scheme 1 A schematic of the orientation of the reactants in a membrane POM catalyst and phenol being oxidized by $\mathrm{H}_{2} \mathrm{O}_{2}$ to $\mathrm{CO}_{2}$.

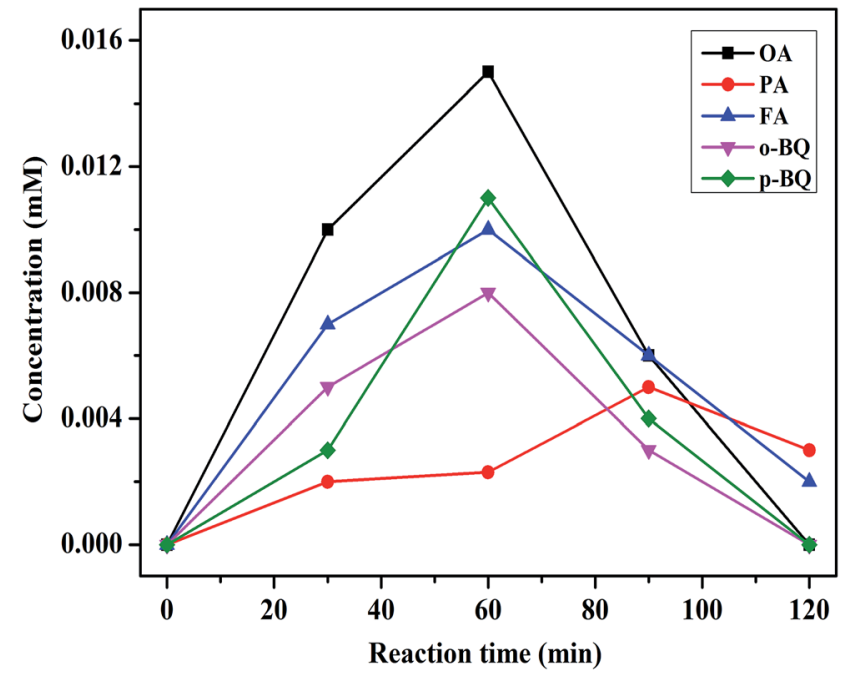

Fig. 10 The concentration of the intermediate products during the reaction. Reaction conditions: $\mathrm{C}_{16} \mathrm{PW}\left(\mathrm{O}_{2}\right)_{2} / \mathrm{PNIPAM}(0.01 \mathrm{~g})$, phenol solution $(0.72 \mathrm{mM}, 5 \mathrm{~mL}), 25{ }^{\circ} \mathrm{C}, 2 \mathrm{~h}$.

catalytic cycle was completed by the reoxidation of $\mathrm{POM}_{\text {red }}$ to its $\mathrm{POM}_{\mathrm{ox}}$ form using $\mathrm{H}_{2} \mathrm{O}_{2} .{ }^{32}$

\section{Conclusions}

In this study, a POM thermosensitive catalyst $\mathrm{C}_{16} \mathrm{PW}\left(\mathrm{O}_{2}\right)_{2} / \mathrm{PNI}-$ PAM was used in the CWPO of phenol under ambient conditions and even at lower temperatures $\left(0^{\circ} \mathrm{C}\right)$. This thermosensitive POM catalyst exhibited high efficiency in active $\mathrm{H}_{2} \mathrm{O}_{2}$ to degrade phenol at $25{ }^{\circ} \mathrm{C}, 10^{\circ} \mathrm{C}$, and even $0^{\circ} \mathrm{C}$ within a short time $(100 \%$ of degradation efficiency) due to the phase changes that occurred upon varying the temperature. The high efficiency of the catalyst was due to the catalytic center of $\mathrm{C}_{16} \mathrm{PW}\left(\mathrm{O}_{2}\right)_{2}$ and the synergistic effects of the polymer support, which enhanced the concentration of phenol molecules around the active sites. Moreover, the temperature-responsive property and high stability are beneficial in the recovery of the catalyst, which exhibited consistent activity for six reaction cycles. Therefore, CWPO based on the POM $\mathrm{C}_{16} \mathrm{PW}\left(\mathrm{O}_{2}\right)_{2} / \mathrm{PNIPAM}$ catalyst is of great value for green chemistry and $\mathrm{C}_{16} \mathrm{PW}\left(\mathrm{O}_{2}\right)_{2} / \mathrm{PNIPAM}$ has potential for the CWPO of phenol especially in low temperature regions.

\section{Conflicts of interest}

There are no conflicts to declare.

\section{Acknowledgements}

This work was supported by the National Natural Science Foundation of China [51578119].

\section{References}

1 J. Guo and M. Al-Dahhan, Ind. Eng. Chem. Res., 2003, 42, 2450-2460. 
2 L. Han, L. B. Qian, J. C. Yan and M. F. Chen, Chemosphere, 2016, 156, 262-271.

3 O. Sacco, V. Vaiano, C. Han, D. Sannino and D. D. Dionysiou, Appl. Catal., B, 2015, 164, 462-474.

4 J. C. Yan, L. Han, W. G. Gao, S. Xie and M. F. Chen, Bioresour. Technol., 2015, 175, 269-274.

5 K. M. Valkaj, A. Katovic and S. Zrncevic, Ind. Eng. Chem. Res., 2011, 50, 4390-4397.

6 N. S. Inchaurrondo, P. Massa, R. Fenoglio, J. Font and P. Haure, Chem. Eng. J., 2012, 198-199, 426-434.

7 D. F. Bishop, G. Stern, M. Fleischman and L. S. Marshall, Ind. Eng. Chem. Process Des. Dev., 1968, 7, 110-117.

8 M. N. Timofeeva, S. T. Khankhasaeva, E. P. Talsi, V. N. Panchenko, A. V. Golovin, E. T. Dashinamzhilova and S. V. Tsybulya, Appl. Catal., B, 2009, 90, 618-627.

9 R. J. G. Lope, M. L. N. Perdigoto and R. M. Quinta-Ferreira, Appl. Catal., B, 2012, 117-118, 292-301.

10 J. W. Singh, J. K. Yang and Y. Y. Chang, J. Environ. Manage., 2016, 175, 60-66.

11 J. Xu, S. Q. Yan, J. X. Li, S. T. Wang, X. H. Wang, M. X. Huo and Z. J. Jiang, RSC Adv., 2014, 4, 25404-25409.

12 S. Zhao, C. L. Sun, L. Wang, X. B. Xu and X. H. Wang, Dalton Trans., 2010, 39, 5087-5090.

13 C. Jaramillo-Páez, J. A. Navío, M. C. Hidalgo, A. Bouzianib and M. E. Azzouzi, J. Photochem. Photobiol., A, 2017, 332, 521-533.

14 B. Zhang, H. Asakura and N. Yan, Ind. Eng. Chem. Res., 2017, 56, 3578-3587.

15 B. Zhang, H. Asakura, J. Zhang, J. G. Zhang, S. De and N. Yan, Angew. Chem., Int. Ed., 2016, 55, 8319-8323.

16 H. C. Li, X. Yu, H. W. Zheng, Y. M. Li, X. H. Wang and M. X. Huo, $R S C A d v ., 2014,4,7266-7274$.
17 J. G. Zhang, Y. Yuan, K. J. Kilpin, Y. Kou, P. J. Dyson and N. Yan, J. Mol. Catal. A: Chem., 2013, 371, 29-35.

18 N. Yan, J. G. Zhang, Y. Yuan, G. T. Chen, P. J. Dyson, Z. C. Li and Y. Kou, Chem. Commun., 2010, 46, 1631-1633.

19 S. C. Sun, X. Yu, Y. N. Guo, L. Chen, X. H. Wang and Z. J. Jiang, Catal. Surv. Asia, 2016, 20, 98-108.

20 Q. Feng, L. Z. Du, Q. Z. Yan and C. C. Ge, Adv. Mater. Res., 2011, 295-297, 1193-1197.

21 Y. F. Cai and C. Y. Wu, Environmental Science Survey, 2012, 31, 85-87.

22 Y. Y. Gu and D. Li, J. Hunan Inst. Sci. Technol., Nat. Sci., 2005, 18, 55-58.

23 C. Venturello and R. D'Aloisio, J. Org. Chem., 1988, 53, 15531557.

24 D. F. Li, Y. H. Guo, C. W. Hu, L. Mao and E. B. Wang, Appl. Catal., A, 2002, 235, 11-20.

25 S. Alexander, G. Pierre and S. L. Kachkarova-Sorokina, Fr. Pat., 2842200, 2004.

26 S. L. Kachkarova-Sorokina, P. Gallezot and A. B. Sorokin, Chem. Commun., 2004, 24, 2844-2845.

27 I. A. Alaton and J. L. Ferry, Dyes Pigm., 2002, 54, 25-36.

28 C. Karunakaran and R. Dhanalakshmi, Sol. Energy Mater. Sol. Cells, 2008, 92, 1315-1321.

29 F. Wu, N. S. Deng and H. L. Hua, Chemosphere, 2000, 41, 1233-1238.

30 S. H. Yoon and J. H. Lee, Environ. Sci. Technol., 2005, 39, 9695-9701.

31 C. Schweitzer and R. Schmidt, Chem. Rev., 2003, 103, 16851757.

32 S. Zhao, X. H. Wang and M. X. Huo, Appl. Catal., B, 2010, 97, 127-134. 